\title{
ANALISIS TRANSAKSI KREDIT PERBANKAN KONVENSIONAL DALAM PENERAPAN KAIDAH KULU QARDHIN JARRA NAF'AN FAHUA RIBA
}

\author{
Oleh : Rachmat risqy K, Ph.D.
}

Ghina Mar'atusholihah

\begin{abstract}
In the distribution of funds, the system adopted by conventional banking in distributing funds is by providing credit or providing financing by banks to their customers. Credit Agreement is an initial process between creditors and debtors that is applied in the conventional banking system in its efforts to develop the funds that have been collected and also to make the best use of the funds. In conventional banking credit agreements there are debt and receivable transactions that are profitable for muqaridh (receivables) so that this is related to the Rules قرض جرم منفعة فهو ربا muqaridh) is usury".
\end{abstract}

Keywords: Agreement, Credit, Conventional Banking, كل قرض جرم منفعة فهو ربا

\begin{abstract}
Abstrak
Dalam penyaluran dana, sistem yang dianut perbankan konvensional dalam menyalurkan dananya dengan pemberian kredit maupun pemberian pembiayaan oleh bank kepada nasabahnya. Perjanjian kredit adalah suatu proses awal antara kreditor dan debitor yang diterapkan dalam sistem perbankan konvensional dalam upayanya untuk mengembangkan dana yang telah dihimpunnya dan juga untuk dimanfaatkan dananya dengan sebaik-baiknya. Dalam perjanjian kredit perbankan konvensional terdapat transaksi hutang piutang yang كل قرض جرم menguntungkan bagi muqaridh (piutang) sehingga hal ini berkaitan dengan kaidah منفعة فهو ربا memiliki arti "setiap hutang piutang yang mendatangkan manfaat (bagi piutang / muqaridh) adalah riba”.
\end{abstract}

Kل قرض جرم منفعة فهو ربا Kata kunci : perjanjian, kredit, perbankan konvensional,

\section{Pendahuluan}

Dari masa ke masa kegiatan ekonomi terus mengalami dinamika perkembangan yang dinamis, selalu berkembang dan berubah seiring dengan perkembangan zaman dan perkembangan pengetahuan manusia. Dimulai pada masa belum dikenalnya institusi pemodal seperti bank, kemudian seiring dengan keutuhan manusia dan berkembangnya zaman, institusi bank tidak dapat di ingkari dalam lingkup kegiatan ekonomi saat ini. ${ }^{1}$ Keberadaan bank

\footnotetext{
${ }^{1}$ abdul salam, dalam perspektif islam (Studi Pendapat Nahhatul Ulama dan Muhamadiyah), jurnal ekonomi Syariah Indonesia, vol. 03, no. $01 \mathrm{hlm} 2$
} 
merupakan salah satu Lembaga perekonomian modern yang perannya tidak bisa dipisahkan dari masalah ekonomi umat manusia secara keseluruhan. ${ }^{2}$

Dalam sistem perekonomian perbankan memiliki peran yang begitu dominan, ia menjadi alat atau instrumen penting dalam jalannya perekonomian masyarakat. Selain menjadi sarana atau tempat menyimpan uang, bank juga merupakan Lembaga intermediary keuangan yang berperan besar dalam menjembatani kepentingan mereka yang memiliki financial surplus dan mereka yang memerlukan pendanaan untuk kepentingan bisnis atau investasi yang bersifat konsumtif. Dalam mekanisme inilah sistem perekonomian mengalami pertumbuhan.

Penyaluran dana dalam bentuk kredit atau Perjanjian dalam pemberian kredit merupakan salah satu hal yang paling penting untuk diperhatikan oleh bank ataupun nasabah, karena hal ini adalah tahap awal bagi bank dan nasabah dalam melaksanakan suatu perjanjian yang telah disepakatinya nanti. Di dalam proses, pemberian kredit yang di lakukan oleh bank konvensional dalam menghimpun dana dengan mengeluarkan kredit kepada debitor. Agar dana yang dihimpunnya dapat berkembang pesat, bank konvensional menawarkan bunga yang menarik kepada debitor, dalam artian yang rendah. Agar debitor dapat mempergiat usahanya yang pada gilirannya dapat memacu pertumbuhan ekonomi. Dari yang kita pahami Bersama bahwa mayoritas bank menjalankan fungsi utamanya diatas menggunakan stimulus atau instrument bunga.

Hal tersebut menyebabkan eksistensi bank cukup urgen menjadi salah satu komponen dalam kegiatan ekonomi masyarakat. Dalam ajaran agama islam kegiatan perbankan merupakan kegiatan bermuamalah, yang kegiatannya boleh dilakukan dengan syarat sesuai dengan aturan-aturan yang ada dalam agama islam. Adapun salah satu ciri dari muamalah yang sesuai dengan syariat islam adalah muamalah yang tidak mengandung unsur riba di dalamnya.

Namun permasalahannya, kegiatan perbankan ini sering dikaitkan dengan bunga bank yang dianggap riba. Bunga bank adalah permasalahan kontemporer dalam bidang ekonomi dan banyak diperbincangkan serta timbul perdebatan mengenai hukum fiqihnya. Ulama dan ahli ekonomi Islam berbeda pendapat tentang hukum bunga bank ini. Setidaknya ada dua kutub pandangan yang berbeda yakni ulama yang memperbolehkan (menghalalkan) bunga bank karena menganggap bunga bank tidak serupa dengan riba dan ada pendapat yang mengharamkannya karena berpandangan bahwa bunga bank adalah salah satu jenis dari riba itu sendiri. Dalam artikel ini akan di bahas perjanjian kredit pada perbankan konvensional dalam al-Qawā‘id al-Fiqhiyah serta penerapan dan usur-unsur yang ada di dalamnya.

\section{Rumusan Masalah}

Mengapa transaksi kredit perbankan konvensional merupakan penerapan dari kaidah kulu qardhin jarra naf'an fahua riba?

\section{Tujuan}

Untuk mengetahui analisis dari transaksi kredit perbankan konvensional yang ada dalam transaksi kredit perbankan konvensional.

\section{Pembahasan}

\footnotetext{
${ }^{2}$ Khoiruddin Nasution, Isu-Isu Kontemporer Hukum Islam, (Yogyakarta: SUKA Press, 2007), hlm.106
} 


\section{Pengertian}

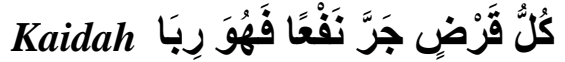

Jika dilihat dari tujuannya transaksi terbagi menjadi berbagai macam salah satunya adalah transaksi yang bertujuan memberikan uluran tangan dan meringankan kesusahan orang lain, misalnya hutang piutang. Transaksi jenis ini biasa terjadi antara orang yang sedang kesusahan, sehingga ia membutuhkan pertolongan orang lain yang memiliki kelapagan dalam hal harta benda atau lainnya. Dalam keadaan ini islam mengajarkan kepada umatnya untuk tidak mengambil kesempatan dalam kesempitan. Bukan sekedar melarang, tapi juga menganjurkan untuk ikut andil dalam melapangkan permasalahan tersebut, yaitu dengan cara memberikan pertolongan dan bantuan. Sebagaimana sabda Nabi Muhammad SAW dalam hadistnya. Yang artinya, "dan allah senantiasa menolong seorang hamba, selama ia menolong saudaranya". ${ }^{3}$ Begitu pula dalam hutang piutang Allah SWT telah menjelaskannya dalam alquran surat al-baqarah ayat 280

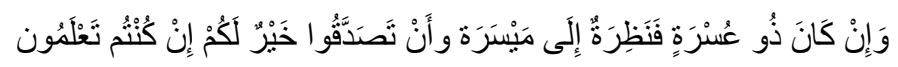

"Dan jika (orang berhutang itu) dalam kesukaran, maka berilah tangguh sampai dia berkelapangan. Dan menyedakahkan (sebagian atau semua hutang) itu lebih baik bagimu, jika kamu mengetahui."

Abu Abdillah Muhammad al-bukhari al-hanafi berkata, "Tidaklah ada orang yang sudi menanggung riba, selain orang yang sedang terhimpit oleh kebutuhan dan kesusahannya. Sehingga, seharusnya orang yang demikian ini dikasihani, disayangi dan ditolong. Oleh karena itu, orang-orang semacam ini biasanya berhak untuk menerima sedekah. Andaikata kita tidak bersedekah, maka paling tidak kita tidak meminta tambahan/bunga atas piutangnya. Akan tetapi, bila kita tetap juga meminta tambahan atas piutangnya, maka sikap ini menunjukkan, bahwa kita benar-benar tidak memiliki rasa iba dan sangat berambisi untuk menumpuk harta. Sudah barang tentu sikap ini tidak layak bagi orang yang beriman, bahwa ia akan meninggalkan kehidupan fana ini." ${ }^{4}$

Ungkapan yang hampir sama juga dilontarkan oleh ibnu taimiyyah, "Pada asalnya, tidaklah ada orang yang sudi untuk bertransaksi dengan cara riba, selain orang yang sedang dalam kesusahan. Bila tidak, maka sudah barang tentu orang yang dalam kelapangan tidak mungkin rela untuk membeli barang seharga 1000 dengan harga 1200 dengan pembayaran dihutang, bila ia benar-benar sedang tidak membutuhkan uang 1000 tersebut. Orang yang rela untuk membeli barang dengan harga yang melebihi harga semestinya hanyalah orang yang sedang dalam kesusahan. Sehingga perbedaan harga kredit dengan kontan tersebut merupakan tindak kezhaliman kepada orang yang sedang mengalami kesusahan... dan riba benar-benar terwujud padanya tindak kezhaliman kepada orang yang sedang kesusahan. Oleh karenanya, riba sebagai lawan dari sedekah. Hal ini karena Allah tidaklah membebaskan orang-orang kaya, hingga mereka menyantuni orang-orang fakir karena kemaslahatan orang kaya dan juga fakir dalam urusan agama dan dunia tidak akan terwujud dengan sempurna, melainkan dengan cara tersebut." 5

\footnotetext{
${ }^{3}$ https://pengusahamuslim.com/1959-kaidah-penting-seputar-transaksi-riba-setiap-keuntungan-daripiutang-adalah-riba.html

${ }^{4}$ (Mahaasin al-Islam oleh Abu Abdillah Muhammad al-Bukhari al-Hanafi, hal. 84)

${ }^{5}$ (al-Qawaid an-Nuraniyah, hal. 116)
} 
Dari sanalah asal syariat islam mengharamkan keuntungan yang diambil dari hutang piutang, disebut sebagai riba yang kemudian ditegaskan hal ini oleh para ulama dalam kaidah

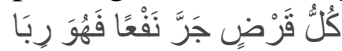

\section{Perbankan Konvensional}

Perbankan konvensional adalah segala sesuatu yang menyangkut tentang bank, mencakup kelembagaan, serta cara dan proses dalam melaksanakan kegiatan usahanya. Sedangkan mengenai bank, secara umum bank adalah bandan usaha yang menghimpun dana dari masyarakat dalam bentuk simpanan dan menyalurkannya kepada masyarakat secara kredit, pembiayaan atau bentuk-bentuk lainnya dalam rangka meningkatkan taraf hidup banyak rakyat. Secara khusus bank konvensional adalah bank yang aktifitasnya, penghimpunannya dan, penyaluran dana nya, memberikan dan mengenakan imbalan berupa bunga atau sejumlah imbalan dalam presentase tertentu dari dana untuk suatu periode. Presentase tertentu ini biasa ditetapkan pertahun.(Budisantoso,2006)

\section{Perjanjian Kredit Dalam Perbankan Konvensional}

Dalam perbankan konvensional memaksimalkan perolehan dana dari masyarakat berupa menawarkan tingkat bunga yang menarik dari nasabah penyimpan dana, yaitu bunga setinggi-tingginya. Bunga simpanan dikatakan menarik jika lebih tinggi dari pada tingkat inflasi, tingkat bunga riil di luar negeri, dan tingkat bunga bank-bank dalam negeri lainnya.

Dalam upayanya untuk mengembangkan dana yang telah di himpunnya mengeluarkan kredit kepada debitor. Agar dana yang dihimpun berkembang pesat, bank konvensional menawarkan bunga kredit yang menarik kepada debitor, dengan serendah-rendahnya, bahkan bisa lebih rendah dari bunga simpanan. Bunga kredit yang rendah membuat pengusaha giat mengembangkan usahanya, yang pada waktunya akan memacu pertumbuhan ekonomi. Jika tidak, dengan tingkat bunga kredit yang tinggi dapat menyebabkan produkifitas masyarakat macet karena pengusaha kekurangan modal (Hendy, 2005).

Di dalam KUHPerdata mengatur perjanjian khusus, namun tidak satupun mengatur tentang perjanjian kredit. Oleh karena itu penetapan mengenai bentuk hubungan hukum antara Bank dan Nasabahnya, yang disebut dengan Perjanjian Kredit Bank itu sebenarnya harus digali dari sumber-sumber di luar KUHPerdata. Dalam hal ini Marhainis telah memperbandingkan kelima belas perjanjian khusus yang diatur dalam KUHPerdata dan menurutnya yang paling mendekati dengan perjanjian kredit adalah pengertian perjanjian pinjam mengganti sehingga apabila terdapat masalah sengketa perjanjian kredit dapat menggunakan dasar hukum perjanjian pinjam mengganti menurut KUHPerdata tersebut. perjanjian kredit termasuk kedalam perjanjian innominat (Salim,2005) yang membuat ketentuannya tidak secara khusus diatur dalam KUHPerdata.

Subjek dari perjanjian kredit adalah pihak kreditor yang berhak atas prestasi dan pihak debitor yang berkewajiban atas prestasi (Harahap,1986). Hal ini hamper sama denga napa yang diatur dalam pasal 1234 KUHPerdata, bahwa prestasi dapat berbentuk memberikna sesuatu, atau tidak berbuat sesuatu.

Kredit dalam arti lain juga bermakna penyediaan uang atau tagihan yang dapat disamakan dengan itu, berdasarkan persetujuan pinjam-meminjam antara bank dengan pihak lain yang mewajibkan pihak pinjaman untuk melunasi utangnya setelah jangka waktu dengan jumlah bunga, imbalan atau pembagian hasil keuntungan (Hay, 1975). 


\section{Riba}

Secara etimologis, riba berarti ziyaadah 'tambahan'. Maksudnya adalah tambahan atas modal, sedikit maupun banyak. ${ }^{6}$ Dalam pengertian lain riba juga mengandung akna tumbuh dan membesar. Secara teknis riba dapat diartikan sesuatu tambahan dari harta pokok yang diambil dengan cara batil. Dalam Ensiklopedi Hukum Islam jilid V, karya Drs. H. A. Hafizh Dasuki, MA, dkk dijelaskan bahwa para ulama fikih mendefinisikan riba sebagai "Kelebihan harta dalam suatu muamalah dengan tidak ada imbalan/gantinya". Maksudnya adalah tambahan harta dari modal pemilik yang ada tanpa adanya imbalan atau gantinya. Seperti harta tambahan yang timbul akibat suatu transaksi utang piutang yang harus diberikan terutama kepada pemilik uang pada saat jatuh tempo. Sebagaimana dalam firman allah SWT. Dalam QS. Al-baqarah ayat 278-279 yang artinya,

"Hai orang-orang yang beriman, bertakwalah kepada Allah dan lepaskan sisa-sisa riba (yang belum dipungut) jika kamu orang-orang beriman. Jika kamu tidak mengerjakanmaka ketahuilah bahwa Allah dan Rasulnya akan memerangimu. Dan jika kamu bertobat bagimu modalmu, kamu tidak menganiaya dan tidak (pula) dianiyaya”.

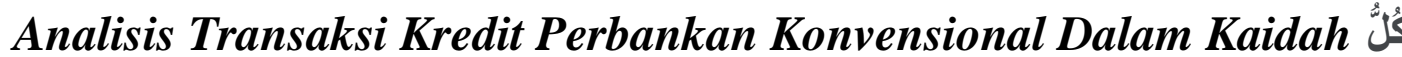

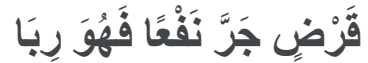

Pada dasarnya, bentuk-bentuk produk penghimpunan dana yang ada pada bank konvensional dengan ank Syariah sama. Bank konvensional maupun bank Syariah sama-sama menghimpun dana dari masyarakat dalam bentuk simpanan berupa giro, tabungan dan deposito. Dalam perbankan konvensional sendiri ada produk yang dikenal dengan kredit dimana nasabah mengajukan suatu pembelian dan membayarnya secara berkala. Dalam perbankan Syariah pun ada namun dengan nama yang berbeda yaitu akad pembiayaan. Dalam akad pembiayaan bank mendapat keuntungan yang berasal dari akad tersebut, sedangkan dalam kredit bank mendapatkan keuntungan yang berasalkan dari bunga bank, dan bunga bank tersebut terus berkembang.

Sebagaiamana yang telah dibahas dalam paper ini seperti apa definisi riba itu sendiri,

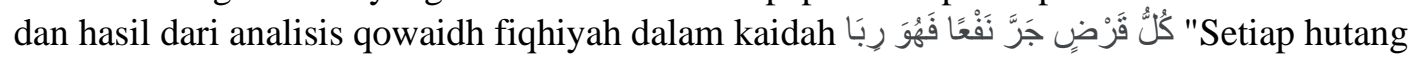
piutang yang mendatangkan manfaat (bagi piutang/muqaridh) adalah riba" adalah transaksi kredit perbankan konvensional mengandung unsur hutang piutang yang menguntungkan bagi muqaridh (piutang) yang menunjukan bahwa transaksi ini mengandung unsur riba dilihat dari kaidah fiqih yang telah disebutkan sebelumnya. Maka transaksi kredit perbankan konvensional tidak boleh dilakukan bagi umat muslim karna ia mengandung unsur riba yang sifatnya adalah haram.

\section{Kesimpulan}

Kredit atau pinjaman adalah suatu penyediaan uang atau yang bisa disamakan dengan tagihan, berdasarkan kesepakatan atau persetujuan pinjam meminjam antara bank dan pihak lain, dimana pihak peminjam wajib membayarkan hutangnya secara lunas selama jangka waktu

\footnotetext{
${ }^{6}$ Dalam buku fiqih sunnah, said sabiq hal. 173
} 
yang ditetapkan dengan pemberian bunga. Dalam kredit bank mendapatkan keuntungan yang berasalkan dari bunga bank, dan bunga bank tersebut terus berkembang.

Sebagaiamana yang telah dibahas dalam paper ini seperti apa definisi riba itu sendiri,

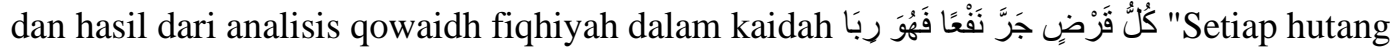
piutang yang mendatangkan manfaat (bagi piutang/muqaridh) adalah riba" adalah transaksi kredit perbankan konvensional mengandung unsur hutang piutang yang menguntungkan bagi muqaridh (piutang) yang menunjukan bahwa transaksi ini mengandung unsur riba dilihat dari kaidah fiqih yang telah disebutkan sebelumnya. 


\section{Daftar Pustaka}

abdul salam, dalam perspektif islam (Studi Pendapat Nahhatul Ulama dan Muhamadiyah), jurnal ekonomi Syariah Indonesia, vol. 03, no. 01 hlm 2

Khoiruddin Nasution, Isu-Isu Kontemporer Hukum Islam, (Yogyakarta: SUKA Press, 2007), hlm.106

https://pengusahamuslim.com/1959-kaidah-penting-seputar-transaksi-riba-setiap-keuntungandari-piutang-adalah-riba.html

Mahaasin al-Islam oleh Abu Abdillah Muhammad al-Bukhari al-Hanafi, hal. 84

al-Qawaid an-Nuraniyah, hal. 116

Dalam buku fiqih sunnah, said sabiq hal. 173 